\title{
Backhoe Trenching on the Banks of the Old San Antonio River at Pyron Avenue, City of San Antonio, Bexar County, Texas
}

Jon J. Dowling

Follow this and additional works at: https://scholarworks.sfasu.edu/ita

Part of the American Material Culture Commons, Archaeological Anthropology Commons, Environmental Studies Commons, Other American Studies Commons, Other Arts and Humanities Commons, Other History of Art, Architecture, and Archaeology Commons, and the United States History Commons

Tell us how this article helped you.

This Article is brought to you for free and open access by the Center for Regional Heritage Research at SFA ScholarWorks. It has been accepted for inclusion in Index of Texas Archaeology: Open Access Gray Literature from the Lone Star State by an authorized editor of SFA ScholarWorks. For more information, please contact cdsscholarworks@sfasu.edu. 
Backhoe Trenching on the Banks of the Old San Antonio River at Pyron Avenue, City of San Antonio, Bexar County, Texas

\section{Creative Commons License}

\section{(c) (i) (8)}

This work is licensed under a Creative Commons Attribution-NonCommercial 4.0 International License 


\section{Backhoe Trenching on the Banks of the Old San Antonio River at Pyron Avenue, City of San Antonio, Bexar County, Texas}

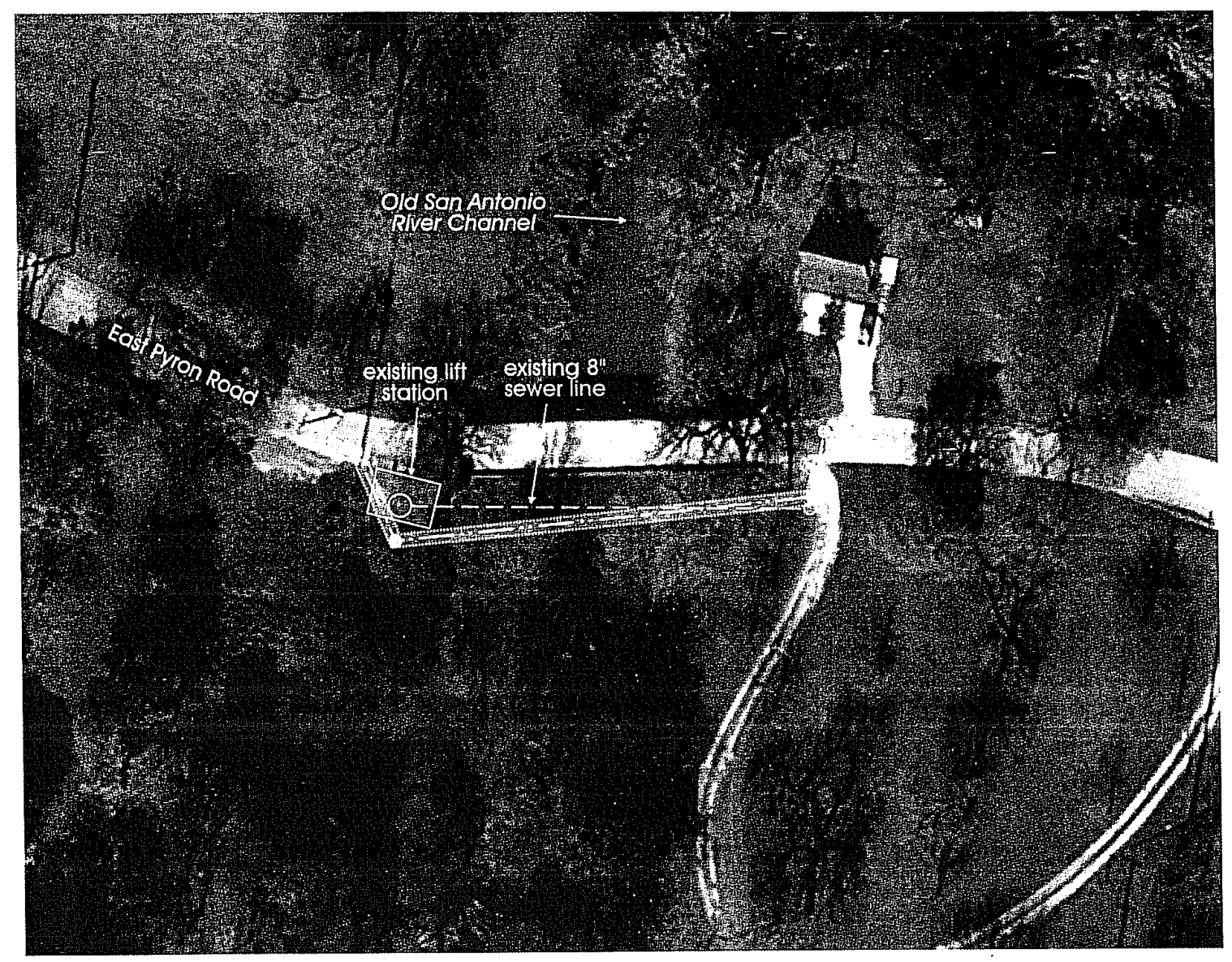

by

Jon J. Dowling

Prepared for:

Bain Medina Bain, Inc.

7073 San Pedro Ave.

San Antonio, Texas 78216

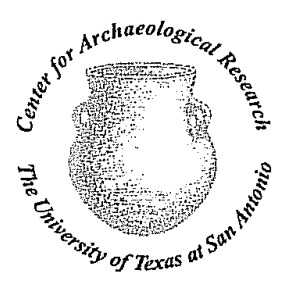

(C)2008
Prepared by:

Center for Archaeological Research The University of Texas at San Antonio Archaeological Report, No. 380 


\title{
Backhoe Trenching on the Banks of the Old San Antonio River at Pyron Avenue, City of San Antonio, Bexar County, Texas
}

\author{
by
}

Jon J. Dowling

Texas Antiquities Committee Permit No. 4732

\section{Principal Investigator}

Steve A. Tomka

Prepared for:

Bain Medina Bain, Inc.

7073 San Pedro Ave.

San Antonio, Texas 78216

BAN WMDM DAN
Prepared by:

Center for Archaeological Research

The University of Texas at San Antonio

Archaeological Report, No. 380

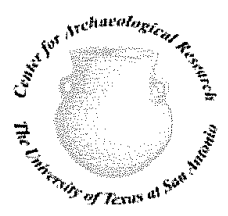




\section{Abstract:}

On December 5, 2007, the Center for Archaeological Research (CAR) at the University of Texas San Antonio conducted archaeological investigations, by means of backhoe trenching, where Pyron Avenue intersects with the Old San Antonio River channel within the footprint of the proposed South Area Lift Station elimination project. Investigations at this location were carried out under Texas Antiquities Permit No. 4732, under contract with Bain Medina Bain Inc. to meet compliance with the City of San Antonio's Unified Code of Development and the requirements of the Texas Antiquities Code. CAR personnel the nature of the deposits within the area targeted for Old San Antonio River channel, south of Pyron Avenue, to examine historic cultural materials that were designated as for sewer-line replacement. Backhoe Trench 1, on the west bank, yielded compromised during the placement of the SAWS lift/pump 41B 1757. The depositional integrity of the deposits was previously Backhoe Trench 2, on the east bank isolated finds. While site 41BXank, exhibited natural soil deposition and also yielded isolated historic artifacts, designated as information limits the research potential of the dealth of historic artifacts, their highly disturbed context and lack of diagnostic not warrant nomination to the National Register of Historic Plate. Therefore, CAR recommends that site 41BX1757 does Further archaeological work is not warranted, and it is the rlaces or formal designation as a State Archaeological Landmark. elimination activities be allowed to progress.

No artifacts were collected during this project and all project-associated documentation is permanently curated at the Center for Archaeological Research as per THC requirements. 


\section{List of Figures:}

Figure 1-1. Area targeted for backhoe trenching within the entire APE

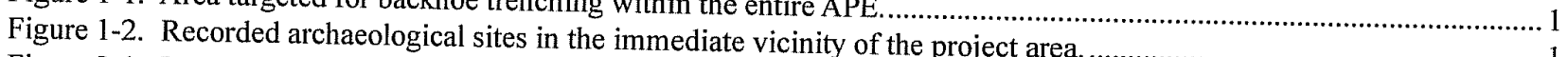

Figure 2-1. Location of Backhoe Trenches 1 and 2, the lift station, and 41 project area................................................... 1

Figure 3-1. Trajectory of existing underground sewer line indicating and $41 \mathrm{BX} 1757$ within the project area.......................... 3

cating disturbed area......................................................5

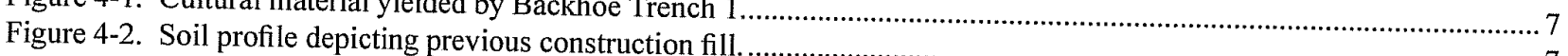

Figure 4-3. SAWS pump station on west bank of Old San Antonio River

Figure 4-4. Non-diagnostic medicine jar fragment unearthed in 


\section{Chapter 1: Introduction}

This report presents the results of archaeological investigations carried out by the Center for Archaeological Research (CAR) of The University of Texas at San Antonio (UTSA) on December 5, 2007. The investigations, consisting of backhoe trenching, were conducted under contract with Bain Medina Bain Inc. along the southern line of East Pyron Avenue at the Old San Antonio River channel crossing. The fieldwork was carried out under Texas Historical Commission Permit Number 4732, with Dr. Steve A. Tomka serving as Principal Investigator. The objective of the archaeological fieldwork was to determine whether undocumented subsurface cultural materials were present within the project Area of Potential Effect (APE) (Figure 1-1).

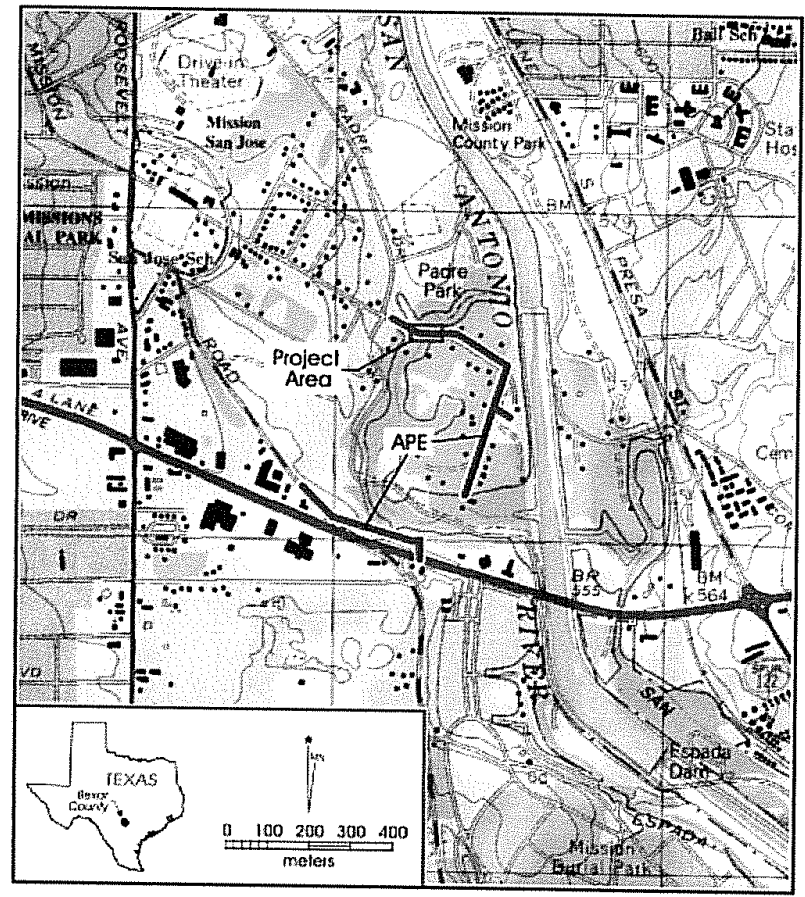

Figure 1-1. Area targeted for backhoe trenching within the entire $A P E$.
The majority of sewer line improvements associated with the South Area Lift Station elimination project affect previously disturbed areas. However, given the large number of prehistoric and historic archaeological sites documented along the San Antonio River, this intersection of Pyron Avenue and the Old San Antonio River channel represented the area of highest probability for containing intact cultural deposits within the project Right-of-Way (ROW). This portion of the project area also is in close proximity to the southeast end of Mission San José's Acequia Media (Figure 1-2), recently documented by CAR personnel (Meissner et al. 2007).

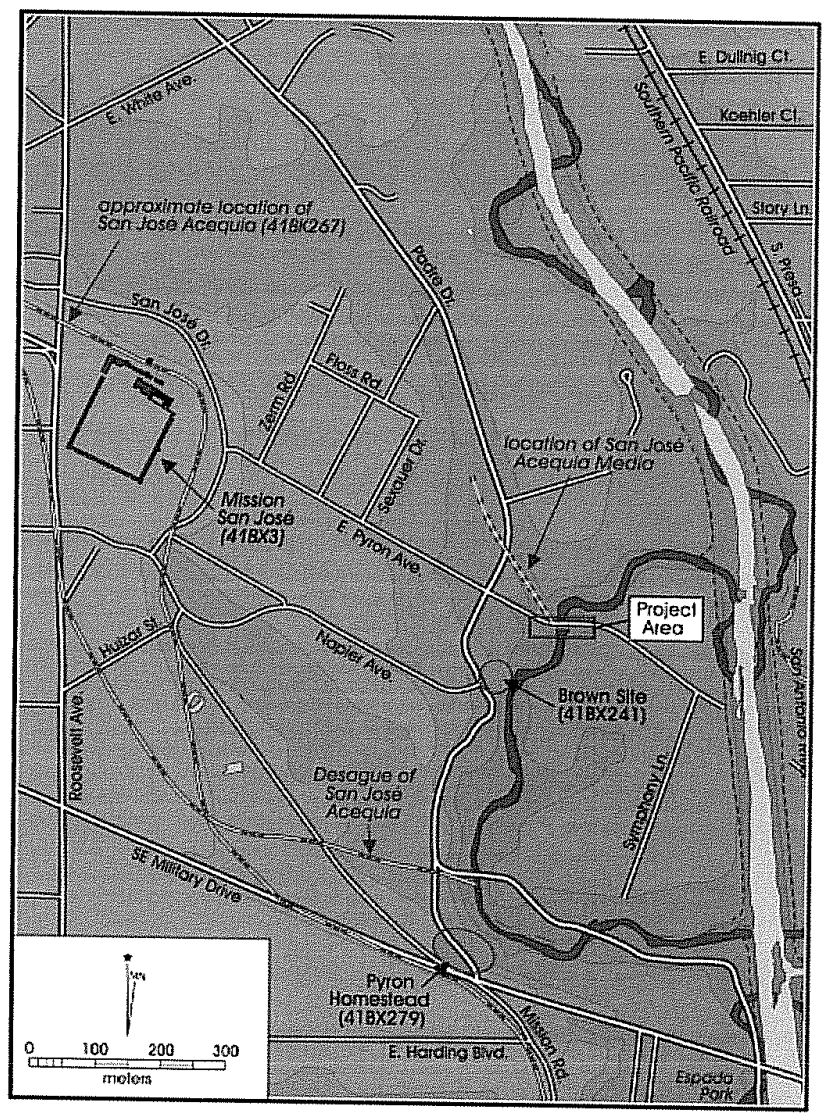

Figure 1-2. Recorded archaeological sites in the immediate vicinity of the project area. 


\section{Chapter 2: Project Area and Previous Archaeology}

Backhoe trenching occurred at a crossing of the Old San Antonio River channel and Pyron Road on both banks (Figure 2-1). This locality is southeast of Mission San José. The surrounding area consists of a riverine drainage basin with colluvial and alluvial deposits. Soils are dark brown clay loams, and vegetation in this area is primarily mesquite, huisache, pecan trees, and various weeds and grasses.

Archaeological work in the vicinity of the project area has been extensive, and only major archaeological undertakings in proximity to the river channel are summarized here (Figure $1-2$ ). Since the 1960 s, numerous archaeological undertakings have been carried out around this segment of the Old San Antonio River channel. The most prominent site in this locality is Mission San José (41BX3). For an in depth summary of work conducted at this site, refer to Tennis (2001:55-61). This Spanish Colonial mission has been subject to at least 16 archaeological investigations. The site contains a granary, a friary, a stone church, mission acequias, and an immense walled enclosure consisting of quarters for Native American neophytes (Habig 1978). The most recent archaeological endeavor in the vicinity of Mission San José, the Mission Trails Project, has successfully located a segment of the San José Acequia Media (Meissner et al. 2007). The Acequia Media is a small branch of the San José Acequia that watered the upper fields of the mission between the river and the San José Acequia. The southern tip of the acequia most likely terminated at the old San Antonio River Channel just north of the project area (Figure $1-2$ ).

Several surveys occurred around the Pyron homestead (41BX279). This site consists of remnants of a house accompanied by several outbuildings, privies, and wells with important research potential (Scurlock et al. 1976; Cox 1992).

Surveys of the multi-component Brown Site (41BX241) yielded project area. several prehistoric stone artifacts and projectile points located around a water well, associated with a historic house structure (Scurlock et al. 1976:80). Remains of the Poor family cemetery are indicated on a map in Scurlock et al. (1976:158), but recent attempts to relocate the cemetery were unsuccessful (Meissner et al. 2007). Also in the immediate vicinity is a Spanish Colonial irrigation ditch (41BX267).

Beginning in the late 1990 s, CAR personnel conducted archival research and provided archaeological services to the City of San Antonio and the Texas Department of Transportation (TxDOT) as part of the Mission Trails Statewide Transportation Project. The project was designed to create a hike and bike trail system connecting the five Spanish missions in San Antonio. Intensive surveying, monitoring, shovel testing, and archaeological backhoe trenching occurred within areas of concern to "assess the potential of an adverse impact to significant cultural resources" (Meissner et al. 2007:i). Sub-surface investigations did not yield any undisturbed cultural deposits, and all artifacts recovered were in mixed context.

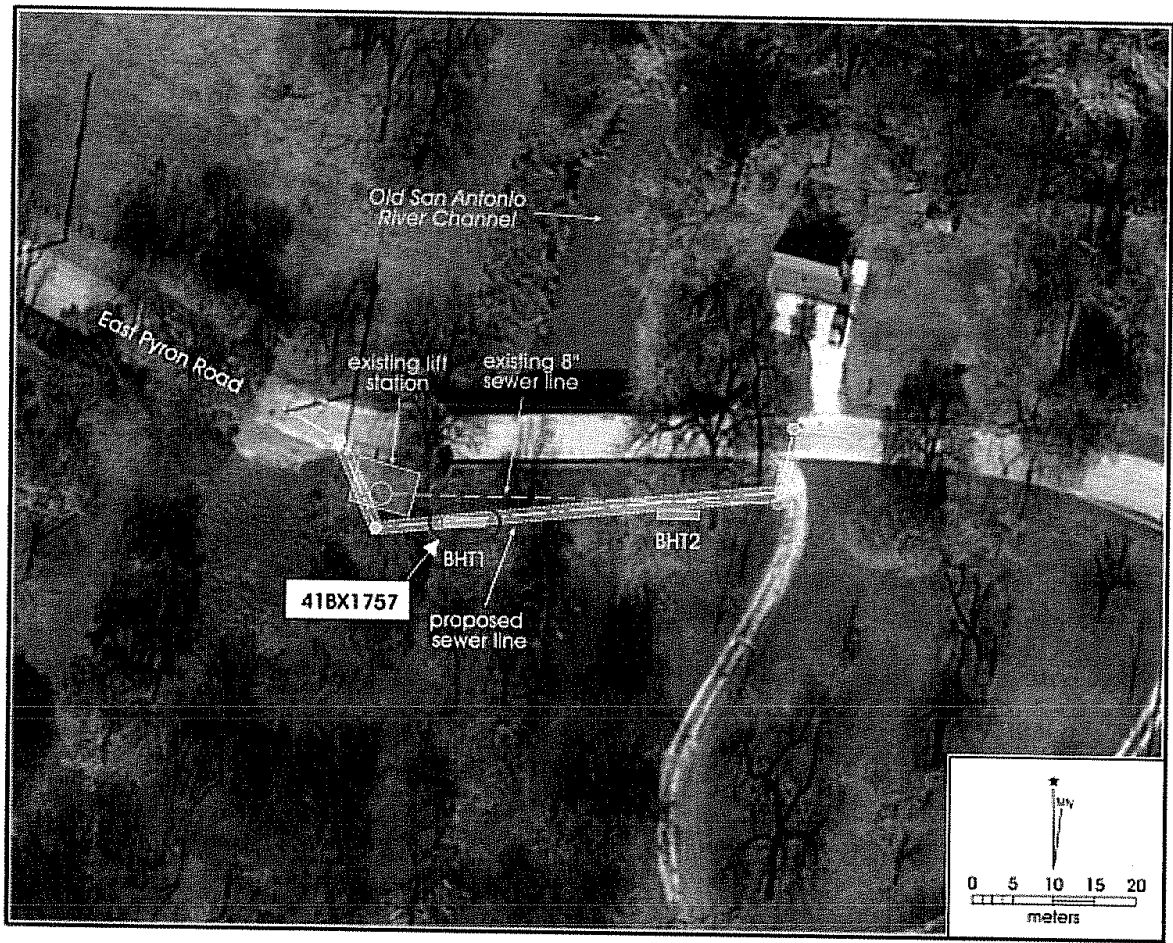

Figure 2-1. Location of Backhoe Trenches 1 and 2, the lift station, and $41 B X 1757$ within the 


\section{Chapter 3: Scope of Work and Field Methodology}

The project area to be investigated by means of backhoe trenching was determined by the project easement boundaries at the Old San Antonio River crossing on E. Pyron Avenue. Before excavation commenced, all geo-locates and utilities along E. Pyron Avenue were identified and marked to preclude accidental damage, and to lessen the likelihood of archaeological investigation in an area known to be disturbed. All utilities were found on the north side of Pyron Avenue where no archaeological work was planned. The south side of E. Pyron Avenue, however, had an 8 inch sewer line that skirted south of the road. SAWS personnel marked the trajectory of the underground sewer line and backhoe trenches were positioned accordingly to avoid it (Figure 2-1 and Figure 3-1).

One trench was excavated on each bank, positioned perpendicular to the Old San Antonio River. Backhoe trenches were one meter wide and five meters long. Neither bedrock nor unsafe/impenetrable obstacles were encountered, and trench dimensions were maintained to a terminal depth of approximately 1.5 meters below ground surface. At all times, excavation was in compliance with Occupational Safety and Health Administration (OSHA) standards for protection of employees in excavations (29CFR1926.652). Soil removed via mechanical means was not screened, but sediments were visually inspected for artifacts upon excavation.

For the purposes of this survey, an archaeological site was required to contain a specific number of cultural materials or features that were at least 50 years old within a given area. The definition of a site used for this project was as follows: (1) Five or more surface artifacts within a 15 meter radius (ca. $706.9 \mathrm{~m}^{2}$ ), or (2) a single cultural feature, such as a hearth, observed on surface or exposed in backhoe trenching, (3) a buried surface containing cultural material exposed in a backhoe trench during excavation.

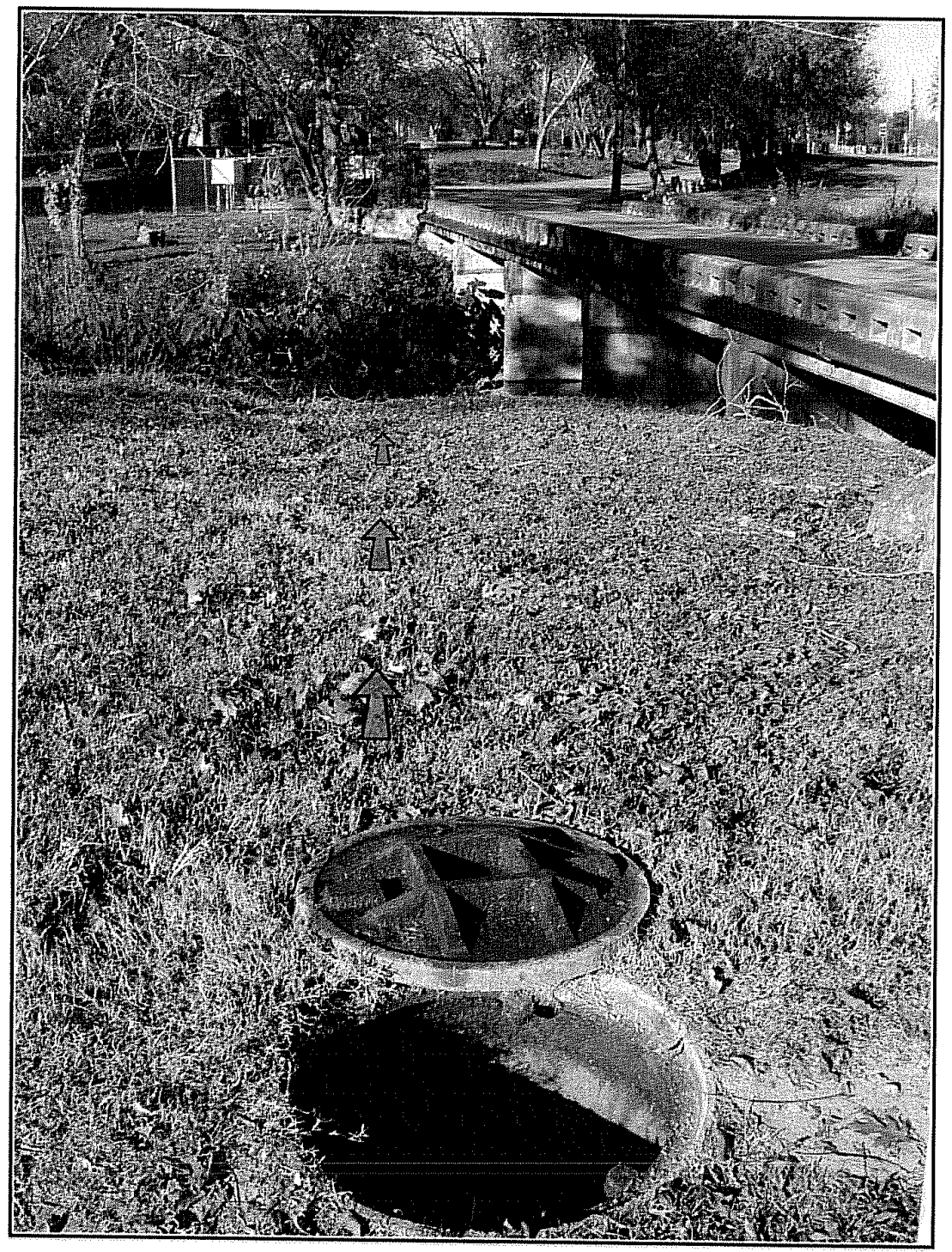

Figure 3-1. Trajectory of existing underground sewer line indicating disturbed area. 


\section{Chapter 4: Results of Investigations}

Each of the two backhoe trenches on the banks of the Old San Antonio River channel revealed cultural materials. BHT 1 on the west bank of the channel yielded historic artifacts $(n=27)$ observed in the backfill. These consisted mostly of non-diagnostic bottle glass of varying colors (Figure 4-1). Other materials included two .22 LR casings, one turkey bone femur fragment, an intact clear glass bottle with a screw top lip with no maker's mark, one wire nail, and one Bristol stoneware ceramic rim sherd. The materials encountered are not temporally diagnostic and were therefore not collected. The .22 long rifle cartridge first appeared in the Marlin Model 1891 lever action rifle, and was eventually adapted to many other rifles and pistols (Logan 1959). This rim-fire round is, to this day, one of the highest selling rounds, and the two badly corroded specimens had lost any distinguishing characteristics

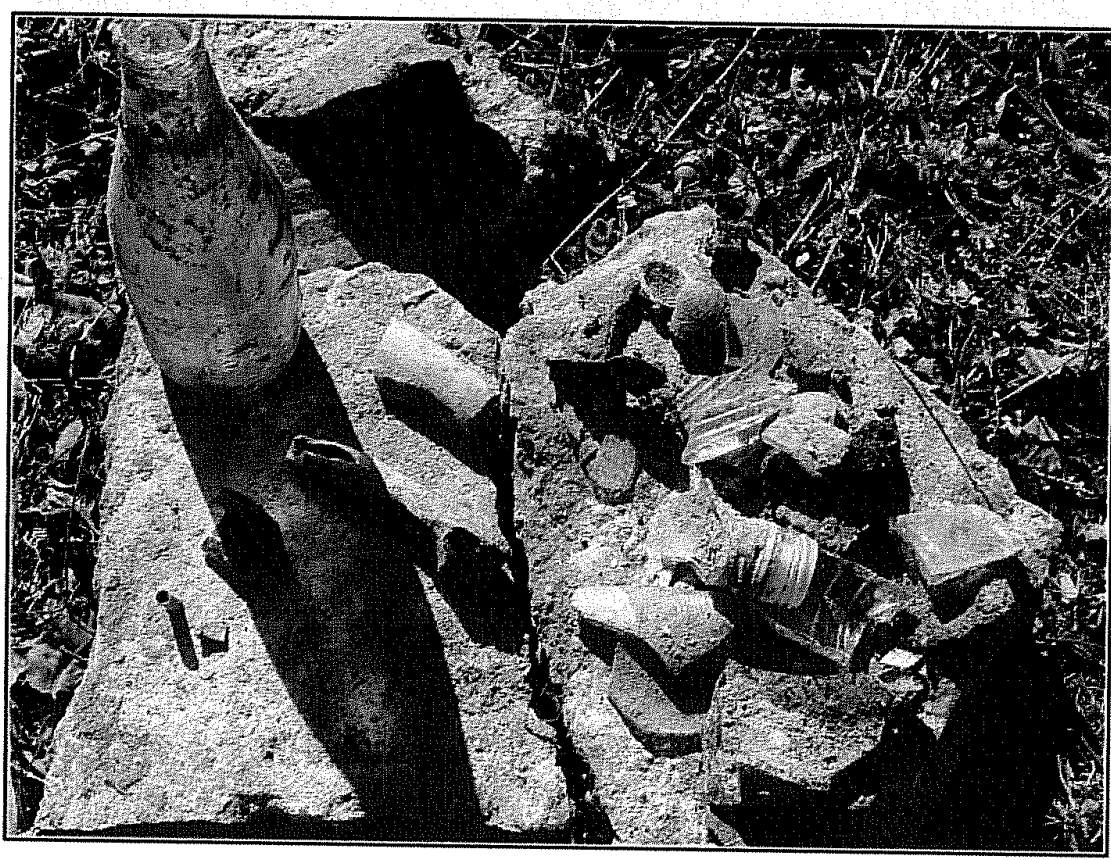

Figure 4-1. Cultural material yielded by Backhoe Trench 1. to be of diagnostic value. Bristol stoneware ceramics, while very common and not colonial, are historic. Stoneware is a dense, hard ceramic with a white, tan or gray paste.

The earliest stoneware in North America dates to the mideighteenth century (Greer 1999:180) and consists primarily of kitchen wares (Zapata et al. 2000:42).

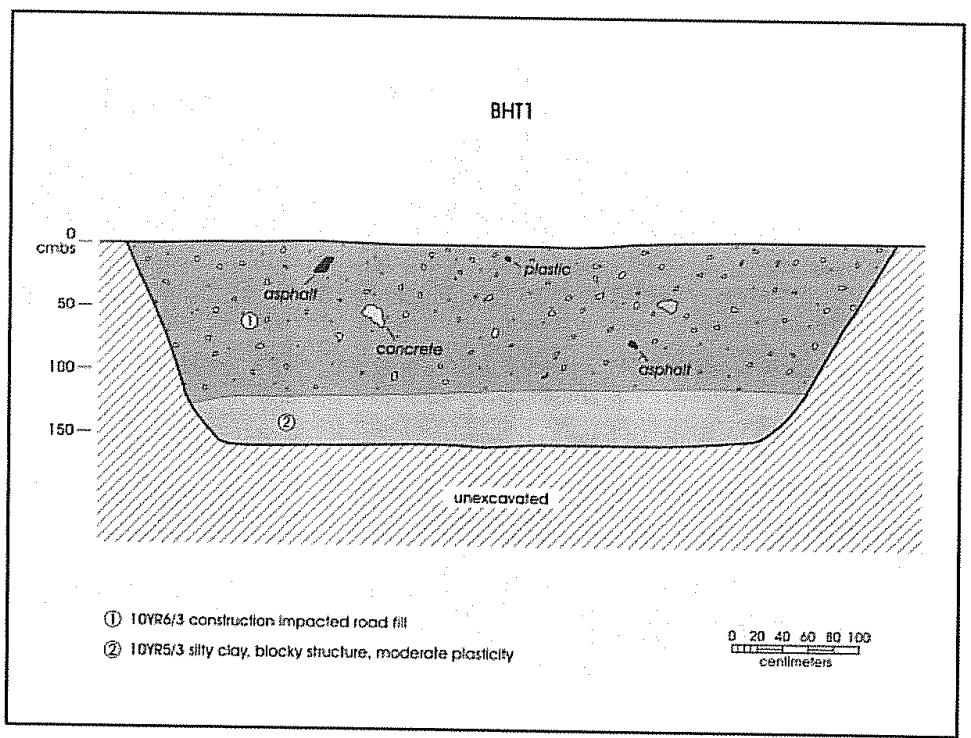

Figure 4-2. Soil profile depicting previous construction fill.
Since more than five artifacts were recovered from less than a 15 meter radius, the area was designated as archaeological site $41 \mathrm{BX} 1757$. Given the limited APE in the project area, the E. Pyron Avenue bridge crossing, and an underground sewer line, the site boundaries could not be established beyond the APE.

All artifacts from BHT 1 were recovered from a stratum consisting of mostly road fill and modern construction materials (Figure 4-2) derived from the SAWS lift/pump station, or wet-well, that was installed September 23, 1976 (Figure 4-3). The installation of this hydrodynamic apparatus required the displacement of a great deal of earth, as did the installation of the 8-inch sewer line that bisects the project area. Therefore, it would seem likely that the cultural material encountered in $\mathrm{BHT} 1$ originated from the immediate area around 


\section{Chapter 5: Conclusions and Recommendations}

Archaeological investigations along the Old San Antonio River channel at the E. Pyron Avenue crossing consisted of one backhoe trench on each bank of the channel. BHT 1 exposed disturbed historic cultural materials, designated as archaeological site $41 \mathrm{BX} 1757$. The deposits have been severely impacted by prior construction and therefore the site does not warrant formal designation as a State Archeological Landmark or nomination to the National Register of Historic Places. Isolated historic artifacts were encountered on the east bank in BHT 2 as well, and the few items were not designated as an archaeological site. Land deed records indicate that this area was part of the original Samuel A. Maverick Estate. Cultural materials found in BHT 1 may represent an isolated debris field associated with this estate. However, the poor depositional integrity of the materials, resulting from the installation of the existing lift station, severely limits the research potential of the deposits. Therefore, the Center for Archaeological Research of The University of Texas at San Antonio recommends that no further archaeological work is needed in the project area and that the proposed South Area Lift Station elimination project be allowed to proceed as planned. 


\section{References Cited}

BCDR (Bexar County Deed Records)

http://www.countyclerk.bexar.landata.com Accessed December 11, 2007.

Cox, I.W.

1992 Archival Investigation of the Pyron Homestead (41BX279), New City Block 7657, San Antonio, Texas. Archaeological Survey Report, No. 210. Center for Archaeological Research, The University of Texas at San Antonio.

Greer, G.H.

1999 American Stonewares: The Art and Craft of Utilitarian Potters. Schiffer Publishing, Ltd., Atglen, Pennsylvania.

Habig, M.A. (compiler)

1978 San José Papers: The Primary Sources for the History of the Mission San José y San Miguel de Aguayo from Its Founding in 1720 to the Present. Part I: 1719-1791. Translated by B. Leutenegger. Old Spanish Missions Historical Research Library at Mission San José, San Antonio, Texas.

Logan, H.C.

1959 Cartridges: A Pictorial Digest of Small Arms Ammunition. Bonanza Books, New York.

Marks, P.M.

1989 Turn Your Eyes Toward Texas: Pioneers Sam and Mary Maverick, Centennial Series of the Association of Former Students, Texas A\&M University, Number 30. Texas A\&M University Press, College Station.

Meissner, B.A., I. W. Cox, J. Weston, and B. Moses, with a contribution by A. Fox

2007 San Antonio Mission Trails Statewide Transportation Enhancement Project Volume 2: Construction Packages 2 and 3: Archaeological Testing and Monitoring Construction of the Mission Trails Hike and Bike Trails, City of San Antonio, Bexar County, Texas. Archaeological Report, No. 374. Center for Archaeological Research, The University of Texas at
San Antonio.

Scurlock, D., A. Benavides, Jr., D. Isham, and J.W. Clark, Jr.

1976 An Archeological Survey of the Proposed Mission Parkway, San Antonio, Texas. Archeological Survey Report 17. Office of the State Archeologist, Texas Historical Commission, Austin.

Tennis, C.L. (editor)

2001 Archaeological Investigations at Four San Antonio Missions: Mission Trails Underground Conversion Project. Archaeological Survey Report, No. 297. Center for Archaeological Research, The University of Texas at San
Antonio.

Zapata, J.E., M.J. Brown, and J.J. Durst

2000 Archaeological Excavation of the Priest Quarters, Mission San Francisco de la Espada, 41BX4, San Antonio, Texas. Archaeological Survey Report, No. 295. Center for Archaeological Research, The University of Texas at San
Antonio. 